\title{
Anticorrosive Effect of Electrochemical Manganese Dioxide By-Products in Reinforced Concrete
}

\author{
N. Chousidis' ${ }^{1}$ E. Rakanta1, I. Ioannou ${ }^{2}$, G. Batis ${ }^{1}$ \\ ${ }^{1}$ School of Chemical Engineering, National Technical University of Athens, Athens, Greece \\ ${ }^{2}$ Department of Civil and Environmental Engineering, University of Cyprus, Nicosia, Cyprus \\ Email: nickhous@central.ntua.gr, erakanta@central.ntua.gr, ioannis@ucy.ac.cy, batis@chemeng.ntua.gr
}

Received 20 March 2015; accepted 24 April 2015; published 27 April 2015

Copyright (C) 2015 by authors and Scientific Research Publishing Inc.

This work is licensed under the Creative Commons Attribution International License (CC BY).

http://creativecommons.org/licenses/by/4.0/

(c) (i) Open Access

\begin{abstract}
The present study investigates the effect of Electrochemical Manganese Dioxide (EMD) by-product as a replacement of cement, on durability of concrete and the corrosion protection of reinforcement steel. Reinforced cement mortars were partially immersed in $3.5 \% \mathrm{w}$. w NaCl solution and they were exposed to atmospheric conditions for a period of 24 months. Additions of $5 \%$ and $10 \%$ EMD byproduct were tested. The following techniques were used: half-cell potential measurements (HCP), linear polarization Resistance (LPR), mass loss of reinforcement steel, determination of carbonation depth of mortars, testing of compressive strength, total and open porosity measurements. Based on the up-to-now results of this study, the specimens with addition $10 \%$ appear smaller corrosion currents and mass loss of steel than reference specimens. Also, the compressive strength with $10 \%$ additive is appeared to be slightly higher from the reference specimens.
\end{abstract}

\section{Keywords}

Pitting Corrosion, Carbonation, Mineral Additives, Electrochemical Manganese Dioxide, Porosity Compressive Strength

\section{Introduction}

The reinforced concrete is the most widely used building material on the world because of high mechanical properties and durability against corrosion. However, the reinforced concrete allows entry of corrosive elements in the mass, thus reducing the life of the constructions. The high porosity and the compressive strength of con- 
crete are related with the type of aggregate which are used and the ratio cement:water [1].

The corrosion of steel in concrete is an electrochemical process which involves the transfer of electrons from one area to another. For corrosion to occur four basic elements are required: Anode is the site where corrosion occurs from which current flows; cathode is the site where corrosion does not occur but to which corrosion current flows; electrolyte is the pore solution in concrete, metallic path which allows current returns and circuit [2].

In normal concrete the embedded steel is protected by the passive oxide layer [3], which is often formed in the high alkaline environment on the steel surface such as concrete pore solution of which the $\mathrm{pH}$ ranges from 12.5 to 13.5 [4]. However, the passivation layer in concrete can be removed by the chemical reaction between the oxide layer and externally intruded chloride ions [5] which decrease the $\mathrm{pH}$ value [6] and the present of carbon dioxide and other acidic gases in the atmosphere can dissolve in the pore solution of concrete and form carbonic acid [7]. The reaction occurs mainly with calcium hydroxide and produces calcium carbonate. The above reaction severely reduces the $\mathrm{pH}$ to as low as 8 and as a result the passivation oxide film is broken out.

The chloride threshold level (CTL) depends from total and free chloride ions and the ratio of [ $\left.\mathrm{Cl}^{-}\right]:\left[\mathrm{OH}^{-}\right][8]$ [9]. The corrosion products over the reinforcement steel due to the larger volume than steel causing tensile stresses with result in cracking of the concrete [10]. Many investigators [11]-[16] have reported the protection of reinforced concrete. The most widely protective methods of reinforced concrete are cathodic protection, organic coatings and mineral additives such as pozzolans (volcanic ash, fly ash), blast furnace slag, silica fume and others. On the other hand, the use of organic and inorganic industrial wastes in concrete contributes to protecting the environment and reducing the cost of production of cement.

The main objective of this study is the theoretical and experimental investigation of the use of EMDW as a replacement of cement for development composite cement structures, resistant in rich chloride environment. Moreover, the used by-product in cement industry helps to reduce $\mathrm{CO}_{2}$ emissions and to protect the environment.

\section{Experimental Procedure}

\subsection{Production of Electrochemical Manganese Dioxide \& By-Products}

The most thermodynamically stable form of manganese dioxide is $\beta-\mathrm{MnO}_{2}$ (pyrolusite), which consists of corner sharing octahedra in the a-b plane, and edge sharing octahedra in the c direction [17]. Ramsdellite has an orthorhombic unit cell and the structure. The $\gamma-\mathrm{MnO}_{2}$ structure is best described as a random microscopic intergrowth between the pyrolusite and ramsdellite forms of manganese dioxide.

The production of Electrochemical Manganese dioxide (EMD) initially includes milling of manganese ore and limestone. After that, leaching with $\mathrm{SO}_{2}$ to form a manganese sulfate solution. The next stage is the removal impurities, potassium, iron and heavy metals from the solution and finally EMD is plated onto titanium anodes and packaged as a fine powder. EMD wastes (EMDW) produced in two stages of filtration/leaching and includes mainly calcium sulphate, ferrous sulphate and heavy metals (Table 3). Electrolytic Manganese Dioxide (EMD) is used as a cathode mixture material for dry-cell batteries, such as alkaline batteries, zinc-carbon batteries, rechargeable alkaline batteries etc. [18]. In Greece EMD produced from TOSOH HELLAS A.I.C. The production process is shown in Figure 1.

\subsection{Materials and Preparation of Mortar Specimens}

Cylindrical reinforcement mortar specimens in diameter $50 \mathrm{~mm}$ and height $100 \mathrm{~mm}$ were prepared. Steel rebars type B500C Tempcore [21] were used with diameter $10 \mathrm{~mm}$ and $100 \mathrm{~mm}$ length. The chemical composition of reinforcement steel is given in Table 1 while the Table 2 presents the chemical analysis of EMD and EMDW.

As is known, the pozzolanic properties of materials related to the existence silicon oxide and its percentage in the additive (EMDW) is insignificant (Table 2). On the basis of chemical composition, the replacement of aggregates (sand) would be more right. However, the choice of specific material has been made because of the fact that EMDW is more fine than cement and likely to improve the mechanical properties of concrete. Moreover, the waste of EMD production process contains heavy metals which are harmful for the environment and the deposition of material costs. The EMDW contains high amounts of $\mathrm{Ca}$ and Fe, therefore reacts on hydration products mainly in C3S and C4AF improving the resistance of concrete against chloride ions. 


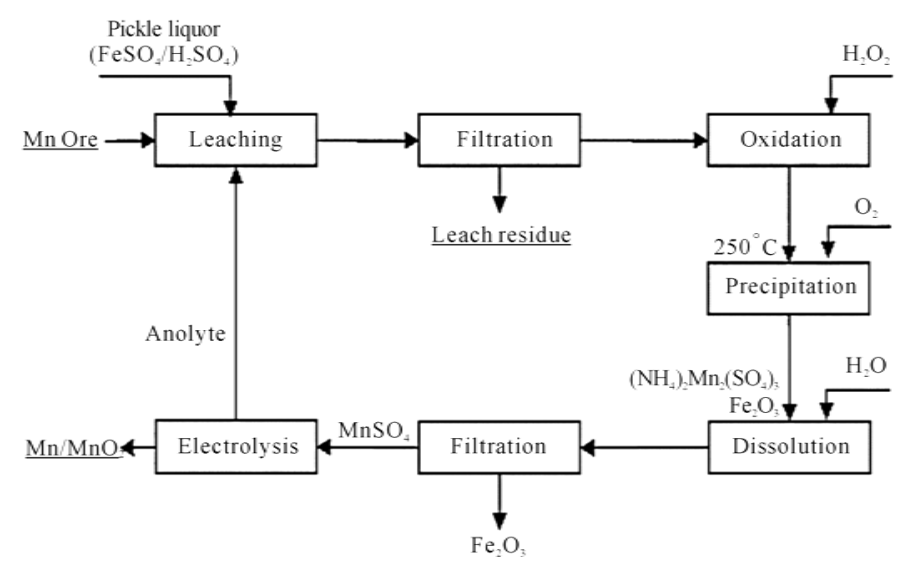

Figure 1. Production process of Electrochemical Manganese Oxide (EMD) [19] [20].

Table 1. Chemical analysis of steel reinforcement.

\begin{tabular}{cccccccc}
\hline & Fe & C & S & P & N & $\mathrm{C}_{\text {eq }}$ \\
\hline B500C Tempcore & $99.168 \%$ & $0.22 \%$ & $0.05 \%$ & $0.05 \%$ & $0.012 \%$ & $0.5 \%$ \\
\hline
\end{tabular}

Table 2. Chemical composition of EMD and EMDW by-product.

\begin{tabular}{ccccccccccccc}
\hline & $\mathrm{MnO}_{2}$ & $\mathrm{H}_{2} \mathrm{O}$ & $\mathrm{Fe}$ & $\mathrm{Ca}$ & $\mathrm{Cu}$ & $\mathrm{Pb}$ & $\mathrm{K}$ & $\mathrm{Na}$ & $\mathrm{Mg}$ & $\mathrm{SO}_{4}^{2-}$ & $\mathrm{As}+\mathrm{Zn}+\mathrm{Co}+$ \\
\hline EMD & 93.0 & 5.0 & 0.004 & 0.03 & 0.0005 & 0.0005 & 0.05 & 0.25 & 0.005 & 1.66 & & $\mathrm{Ni}$ \\
EMDW $^{1}$ & - & - & 9.8 & 15.0 & 0.082 & 0.07 & 0.65 & 0.23 & 0.37 & Unknown $^{2}$ & $\approx 3 \%$ \\
\hline
\end{tabular}

${ }^{1}$ All metals are in the form of sulfate compounds e.g gypsum, Alunite, Jarosite; ${ }^{2}$ The percentage of $\mathrm{SO}_{4}^{2-}$ was not calculated from TOSOH HELLAS A.I.C industry.

The specimens were prepared by mixing cement, calcite sand and water from supply network in ratio 1:3: 0.65. The Portland cement used were CEM I $42.5 \mathrm{~N}$ and the chemical composition presents in the Table 3 . The mortar specimens contained 5\% w. w and 10\% w. w by-product (EMDW) used as a replacement of cement. The mineral additive that was used consists mainly of alunite, yarosite, gypsum and sulphate salts of heavy metals.

The steel rebars were cleaned before installation into the mortars according to ISO/DIS 8407.3 [22] and weighted to a $0.1 \mathrm{mg}$ accuracy. The specimens remained molded for $24 \mathrm{~h}$ and after removing the cast they were fully immersed into water for 7 days under laboratory conditions. A copper wire was enwrapped to each steel rebar to obtain electrochemical measurements. The dimensions and shape of the test specimens are shown in Figure 2. The corrosive environment and the conditions of exssperiments are given in Table 4.

The compressive strength of concrete was measured in cubic concrete specimens $\left(15 \times 15 \times 15 \mathrm{~cm}^{3}\right)$. The molds were filled with fresh concrete and vibrated for consolidation using a vibrating table with frequency 3000 Hz. For preparing of specimens were used calcite aggregates, Greek Portland cement CEM I $42.5 \mathrm{~N}$ and water of Attica network supply. The specimens after being demolded were placed in water in curing room ( $\mathrm{RH}>98 \%$, $T=20^{\circ} \mathrm{C} \pm 1.5^{\circ} \mathrm{C}$ ) for 7 days. Three groups of samples were developed. The first group with aggregates and OPC (reference), the second group including 5\% EMDW and the third group with 10\% EMDW. The ratio of mixing materials of concrete is presented at the Table 5 .

The specimens were constructed in the laboratory of reinforced concrete at TITAN cement plant. The mixture proportions and the characteristics of concrete are summarized in Table 6.

\subsection{Methods}

\subsubsection{Electrochemical Measurements}

- Linear Polarization Resistance (LPR) technique for measurement corrosion rate, corrosion current (i), and pola- 


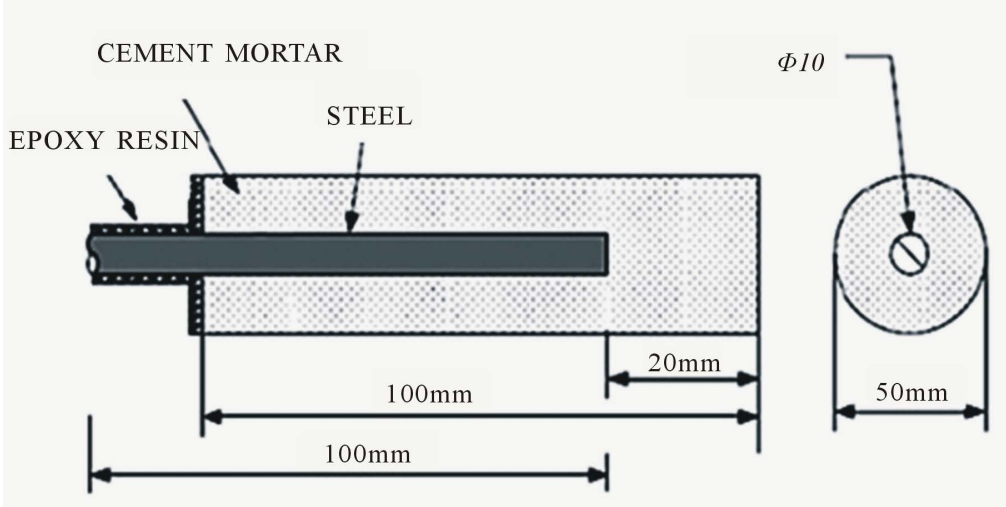

Figure 2 . Schematic representation of reinforced mortar specimen.

Table 3. Chemical analysis and mineralogy of Portland cement.

\begin{tabular}{|c|c|c|c|c|c|c|c|}
\hline \multicolumn{8}{|c|}{ Chemical composition of cement CEM I 42.5N\% } \\
\hline $\mathrm{SiO}_{2}$ & $\mathrm{AlO}_{3}$ & $\mathrm{Fe}_{2} \mathrm{O}_{3}$ & $\mathrm{CaO}$ & $\mathrm{MgO}$ & $\mathrm{SO}_{3}$ & $\mathrm{Na}_{2} \mathrm{O}$ & $\mathrm{K}_{2} \mathrm{O}$ \\
\hline 19.64 & 4.62 & 3.27 & 63.59 & 1.91 & 3.03 & 0.38 & 0.62 \\
\hline \multicolumn{8}{|c|}{ Mineralogy composition of cement \% (according Bogue equations) } \\
\hline & & \multicolumn{2}{|c|}{$\mathrm{C} 2 \mathrm{~S}$} & \multicolumn{2}{|c|}{ C3A } & \multicolumn{2}{|c|}{$\mathrm{C} 4 \mathrm{AF}$} \\
\hline & & \multicolumn{2}{|c|}{12.6} & \multicolumn{2}{|c|}{6.6} & \multicolumn{2}{|c|}{11.0} \\
\hline
\end{tabular}

\section{Table 4. Corrosive environment and conditions.}

\begin{tabular}{cccc}
\hline Corrosive environment & Number of specimens & Period & Conditions \\
\hline Partial immersion in Sodium Chloride & 24 & 24 months & $C_{\mathrm{NaCl}}=3.5 \% \mathrm{w} . \mathrm{w}, T_{\text {aver }}=25^{\circ} \mathrm{C}$ \\
Exposure to Atmospheric conditions & 24 & 24 months & $\begin{array}{l}T_{\text {aver }}=17.85^{\circ} \mathrm{C}, R H_{\text {aver }}=61.4 \%, \\
\text { rainfall }\end{array}$ \\
\hline
\end{tabular}

Table 5. Ratios of materials of concrete specimens for testing of compressive strength.

\begin{tabular}{ccccc}
\hline & Cement & C/W & Additive EMDW & Sand:crushed:stone:gravel \\
\hline Reference & 1 & 0.57 & - & $0.40: 0.35: 0.25$ \\
5\% w. w EMDW & 0.95 & 0.57 & 0.05 & $0.40: 0.35: 0.25$ \\
10\% w. w EMDW & 0.9 & 0.57 & 0.1 & $0.40: 0.35: 0.25$ \\
\hline
\end{tabular}

rization Resistance $\left(\mathrm{R}_{\mathrm{P}}\right)$ according with standard ASTM G59-97 [23]. The technique was developed based on Stern-Geary equation [24]. Tests were conducted using a Potentiostat/Galvanostat Model 263A from EG \& G Princeton Applied Research and an associated software package to analyze the obtained data. The Steel rebars represented the working electrode, calomel was the reference electrode and a carbon bar was the counter electrode. The potential scan range was $\pm 15 \mathrm{mV}$ from OCP and the scan rate was $0.1 \mathrm{mV} / \mathrm{s}$.

- Half-cell Potential (HCP) was measured for a period 24 months using calomel reference electrode (SCE) according with Standard ASTM C876-87 [25]. The measurements were initially recorded on an everyday basis for a period 10 days and then they were recorded on a weekly basis.

\subsubsection{Carbonation Depth}

The specimens were breaking and spraying the fresh cut sample with a $\mathrm{pH}$ indicator $(1 \% \mathrm{w}$. w phenolphthalein 
Table 6. Mixture proportions and concrete characteristics.

\begin{tabular}{ccccccccc}
\hline $\begin{array}{c}\text { Concrete } \\
\text { type }\end{array}$ & $\begin{array}{c}\text { Max } \\
\text { grain }\end{array}$ & Cement & Slump & C/W & $\begin{array}{c}\text { Amount } \\
\text { of cement }\end{array}$ & $\begin{array}{c}\text { Pore } \\
\text { volume }\end{array}$ & $\begin{array}{c}\text { Spesific gravity } \\
\text { of aggregates }\end{array}$ & $\begin{array}{c}\text { Total amount } \\
\text { of aggregates }\end{array}$ \\
\hline $\mathrm{C} 20 / 25$ & $3.5 \mathrm{~mm}$ & $\mathrm{I} 42.5 \mathrm{~N}$ & $\begin{array}{c}\mathrm{S} 2 \\
(50-90 \mathrm{~mm})\end{array}$ & 0.57 & $351 \mathrm{~kg} / \mathrm{dm}^{3}$ & $15 \mathrm{dm}^{3}$ & 2.65 & $1784 \mathrm{~kg} / \mathrm{m}^{3}$ \\
\hline
\end{tabular}

in ethanol) according with the method RILEM CPC-118 [26]. The specimens were exposed at the atmosphere conditions for 24 months and they were breaking every 6 months.

\subsubsection{Gravimetric Mass Loss Measurements}

To evaluate corrosion of steel reinforcement from chloride ions, mortar specimens were broken every 6 months. The steels were cleaned and de-rusted according to ISO/DIS 8407.3. The percentage of mass loss and Corrosion Rate (CR) were calculated from the following equations:

$$
\begin{gathered}
\% \text { mass loss }=\frac{M_{\text {initial }}-M_{\text {final }}}{M_{\text {initial }}} \times 100 \% \\
\text { Corrosion Rate }(\mu \mathrm{m} / \mathrm{y})=\frac{8.76 \times 10^{7} \times W}{A \times T \times D}
\end{gathered}
$$

where $M_{\text {initial }}$ is the mass of steel at the beginning, $M_{\text {final }}$ is the mass after immersion in $\mathrm{NaCl} 3.5 \% \mathrm{w} . \mathrm{w}, W$ is the metal mass loss (g), $A$ is the rebar's surface $\left(\mathrm{cm}^{2}\right), T$ is the time of exposure (h) and $D$ is the density of steel (7.8 $\left.\mathrm{g} / \mathrm{cm}^{3}\right)$.

\subsubsection{Compressive Strength and Slump of Concrete}

The slump of fresh concrete and compressive strength were measured according to ASTM C-143 [27] and BS EN 12390 - 3 [28] standards respectively. The measurements were performed at 7 and 28 days after curing in tanker with water. The loading rate of compression was $13.5 \mathrm{kN} / \mathrm{sec}$ and the max load of machine was $3000 \mathrm{KN}$.

\subsubsection{Total \& Capillary Porosity of Concrete}

- Total porosity of cement mortars. Porosity and pore size of mortar specimens were determined by Mercury intrusion Porosimetry (MIP). MIP method is based on the Washburn [29] equation:

$$
p \times r=-2 \times y \times \cos \theta
$$

where $r$ is the radius of the pore where mercury intrudes, $\gamma$ surface tension of mercury and $\theta$ the contact angle of the mercury on the surface of a solid sample. The total porosity was measured using Carlo Erba 2000 Mercury porosimeter. The mortars exposed to the atmosphere for 18 months and they were broken at 6 and 18 months.

- Capillary porosity of concrete. Determination of open porosity described by many authors [30] [31] as follows: Initially, the samples are dried in an oven $\left(\right.$ at $\left.105^{\circ} \mathrm{C}\right)$ to remove the majority of physically-bound water. They were then placed in an airtight container and the pressure was lowered gradually to $2000 \mathrm{~Pa}$ using a vacuum pump for $3 \mathrm{~h}$. Once the samples were immersed, the liquid supply was stopped and the specimens were kept immersed for the next $24 \mathrm{~h}$. During this time, the absolute air pressure in the container did not exceed 2000 $\mathrm{Pa}$. The vessel was then returned to atmospheric pressure and the specimens were left immersed for another $24 \mathrm{~h}$.

From the mass of the liquid-saturated sample $M_{w}$ and the mass of the immersed liquid-saturated sample $M_{a}$, the volume $V$ of the sample was determined:

$$
V=\frac{M_{w}-M_{a}}{\rho}
$$

where $\rho$ is the density of water. The open porosity was calculated by:

$$
\Psi_{o}=\frac{M_{w}-M_{d}}{V \times \rho}
$$

where $M_{d}$ is the mass of the dry sample. 


\section{Results and Discussion}

The Half-cell potential ( $E_{\text {corr }}$ ) shows, the tendency of steel for corrosion and does not reflected the corrosion rate of reinforcement which is affected by number of factors such as the diffusion of oxygen, concrete's porosity and the presence of highly resistive layer [32]. The Table 7 appears the corrosion condition of steel relative to corrosion potential $\left(E_{\text {corr }}\right)$.

In Figure 3, are presented the corrosion potentials versus exposure time for cement mortars specimens with $5 \% \mathrm{w} . \mathrm{w}$ and $10 \% \mathrm{w}$. w replacement of cement with EMDW and immersion in 3.5\% w. w NaCl solution for a period of 24 months. The reference specimens were prepared for comparison reasons and the ratio of cement:sand:water was 1:3:0.65. A saturated Calomel electrode (SCE) was used as reference electrode.

At the beginning of immersion, reference specimens have higher values of corrosion potential than other two categories. After two months of exposure reference have almost the same $E_{\text {corr }}$ with 5\% EMDW but the mortars with $10 \%$ addition have the most electronegative values due to high porosity. The values of corrosion potentials all of categories of specimens after 24 months partial immersion in $\mathrm{NaCl}$ solution are between $-600 \mathrm{mV}$ to -400 $\mathrm{mV}$ and according to Broomfield the corrosion of steel is severe. The presence of chloride ions and the high relative humidity, corrode the steel reinforcement and decrease the values of $E_{\text {corr }}$.

Figure 4 presents the corrosion potentials in fuction of time, for exposed specimens in atmosphere for 24 months. In contrast the previous chart, the corrosion potentials values are presented less electronegatives. From the graph seems that the corrosion potentials ranging between $-300 \mathrm{mV}$ and $+150 \mathrm{mV}$ and therefore the steel reinforcements are in passive condition and trend does not corrode according to ASTM C876-87.

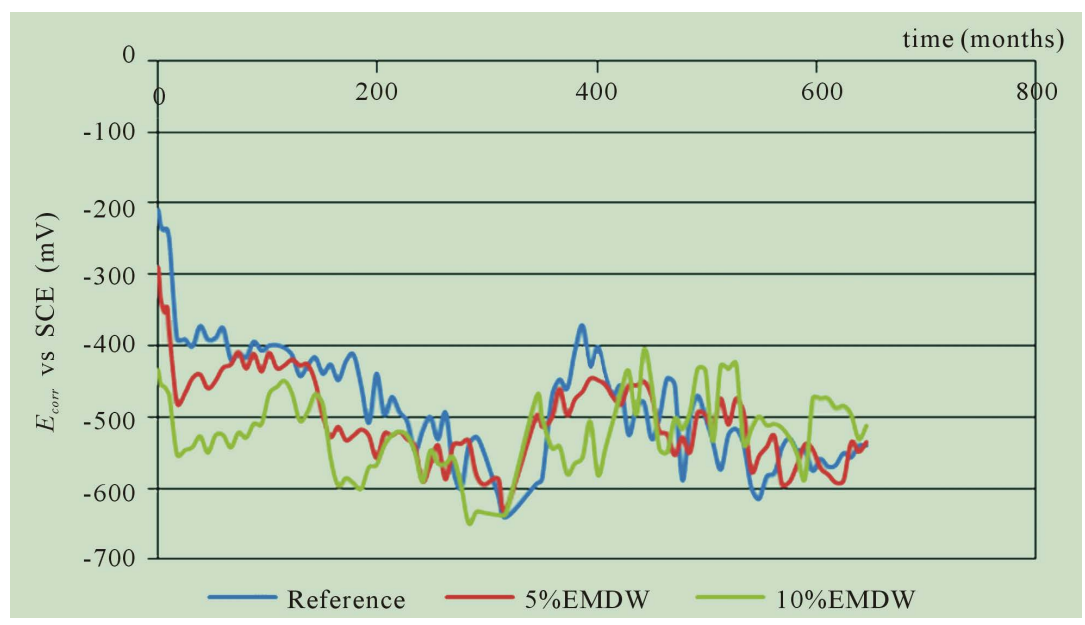

Figure 3. Corrosion potential for reinforced mortars immersed in $3.5 \% \mathrm{w}$. w $\mathrm{NaCl}$ solution.

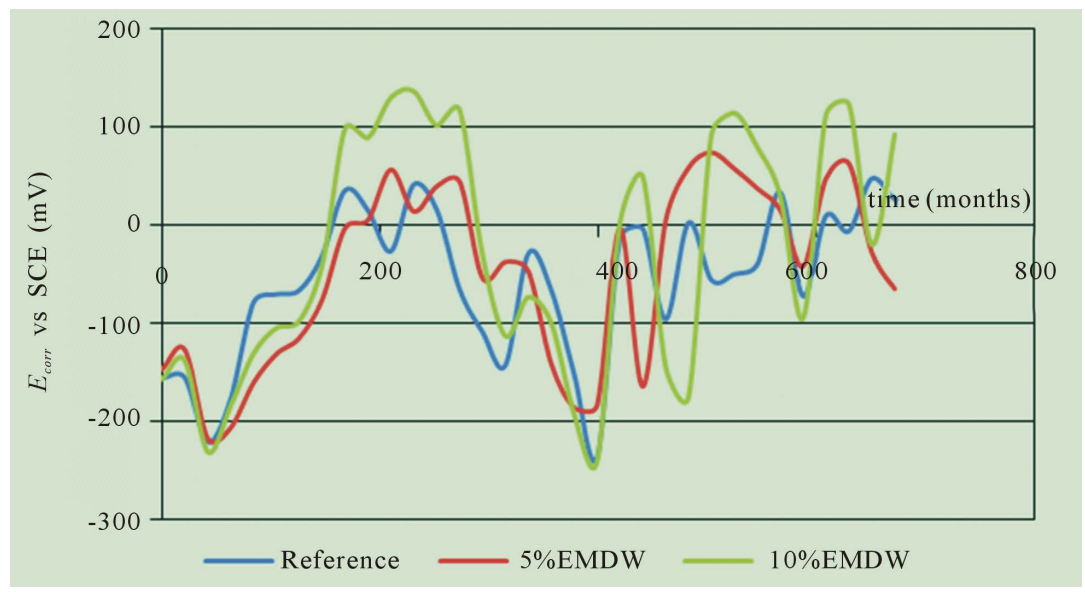

Figure 4. Corrosion potential (mV) for reinforced mortars exposed in atmosphere. 
Table 7. Corrosion condition according (Broomfield, 2003).

\begin{tabular}{cc}
\hline$E_{\text {corr }}$ vs SCE & Corrosion condition \\
\hline$>-126 \mathrm{mV}$ & Low (10\% risk corrosion) \\
$-12 \mathrm{mV}$ to $-276 \mathrm{mV}$ & Intermediate \\
$<-276 \mathrm{mV}$ & High (90\% risk corrosion) \\
$<-426 \mathrm{mV}$ & Severe corrosion \\
\hline
\end{tabular}

The corrosion current $\left(i_{\text {corr }}\right)$ was measured every two months with LPR method and the theoritical mass loss is calculated by Faraday’s law. From Farady’s law:

$$
m(g)=\frac{t \times i \times M}{Z \times F}
$$

where, $m$ is the theoretical mass loss (g), $t$ is the time (s), $i$ is the current (A), $M$ is the atomic weight of iron ( $55.847 \mathrm{~g} / \mathrm{mol}), \mathrm{z}$ is the ion chance (for Fe is 2$), F$ is the Faraday's constant $(96.487 \mathrm{~A} \times \mathrm{s}$ ).

Figure 5 is presented the results of theoritical mass loss measurements. After 7 months of partial immersion in $\mathrm{NaCl}$ 3.5\% w. w, the embedded steels of mortars with EMDW appear lower values of mass loss compared with reference. At the end of measurements, the reference specimens have $49 \%$ higher value from $5 \% \mathrm{w}$. w EMDW and 32\% from 10\% w. w EMDW. High concentrations of calcium and iron of EMDW contributes to the hydration of cement reducing the permeability and porosity of concrete (Figure 10). Based on other studies [33] LPR and HCP are the most suitable methods of detection of steel depassivation and the most influence factors of chloride threshold values is the steel-concrete interface and the steel potential. Analysis of theoritical mass loss by LPR method and gravimetric mass loss show that the replacement of cement up to 10\% decreased the corrosion of steel embedded in concrete.

Figure 6 is presented the carbonation depth $(d)$ versus time of cement mortars exposed in atmosphere. From this graph seems that the addition of EMDW decrease the carbonation depth in comparison with reference after 24 months exposure to the atmosphere. The carbonation depth was calculated according the function [34]:

$$
d=K \times \sqrt{t}
$$

where, $d$ is the carbonation depth in mm, $t$ is the exposure time in yrs., $K$ is the diffusion coefficient of $\mathrm{CO}_{2}$ in $\mathrm{mm} / \mathrm{yr}^{1 / 2}$.

The mass loss of steel embedded in cement mortars is shown at the Figure 7 . The specimens with $10 \%$ EMDW have the lowest values of mass loss compared to the other two categories of specimens. The low values of mass loss due to the decrease of the porosity of specimens with the additive (Figure 10).

The Corrosion Rate (CR) of steels, calculated according with the function (2). The results of measurements are shown to the Figure 8. Corrosion rate increases to all categories of specimens for a period of 24 months. The replacement of cement by 5\% and 10\% EMDW decrease the corrosion rate against chloride ions after 24 months partial immersion in $3.5 \% \mathrm{w}$. w $\mathrm{NaCl}$ solution compared with reference.

The slump and the density of concrete are given in Table 8. The replacement of cement by EMDW was 5\% and $10 \%$ and the ratio $\mathrm{W} / \mathrm{C}=0.57$. Figure 9 illustrates the compressive strength of concrete at 7 and 28 days after curing in water for 7 days. The specimens with $10 \%$ additive have slightly increased compressive strength while the other two categories almost similar. The reduction of total porosity (Figure 10) leads to increased compressive strength.

The porosity was measured by mercury intrusion Porosimetry technique and illustrates in Figure 10. After 18 months of exposure to the atmosphere $C$ the specimens have the same percentage of porosity. The porosity of mortars with 10\% EMDW was reduced 53, 5\% and reference was reduced 35\%.

The results of open porosity measurements of concrete after 130 days exposure to chloride solution is given in Figure 11. Three groups of specimens were made. Two groups with replacement of cement by $5 \%$ and $10 \%$ EMDW and one group without additive (reference) for comparing reasons. The specimens were cubic (100 $\times$ $100 \times 100 \mathrm{~mm}^{3}$ ), and they were prepared by calcite aggregates, CEM I 42.5N, water from Nicosia supply network and ratio $W / C=0.65$. 


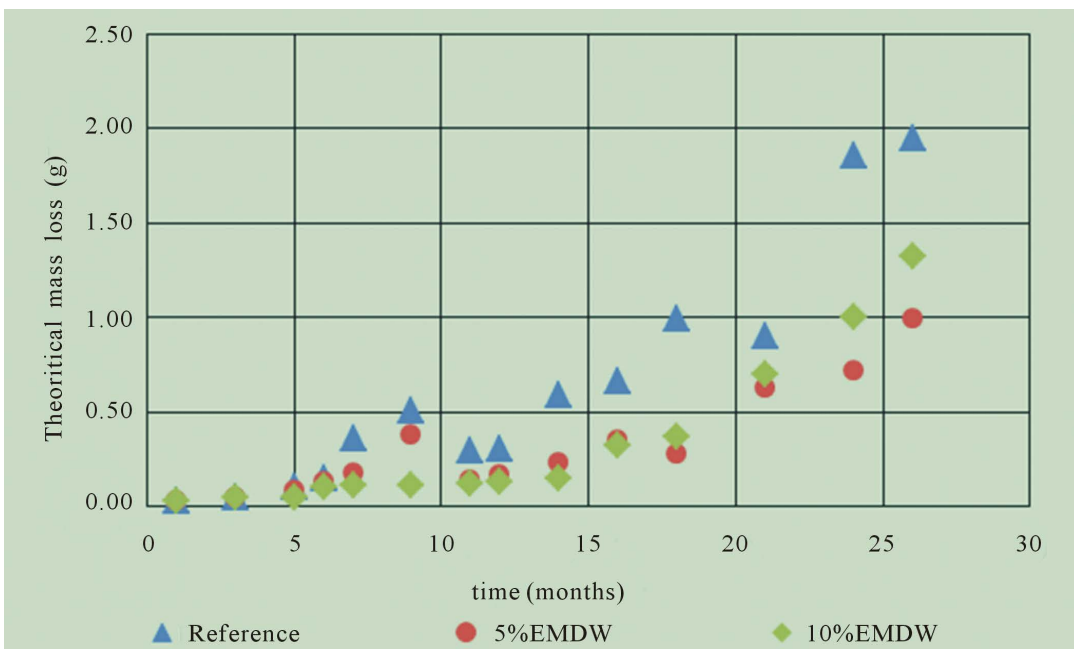

Figure 5. Theoretical mass loss (g) calculated by Faraday’s law versus time.

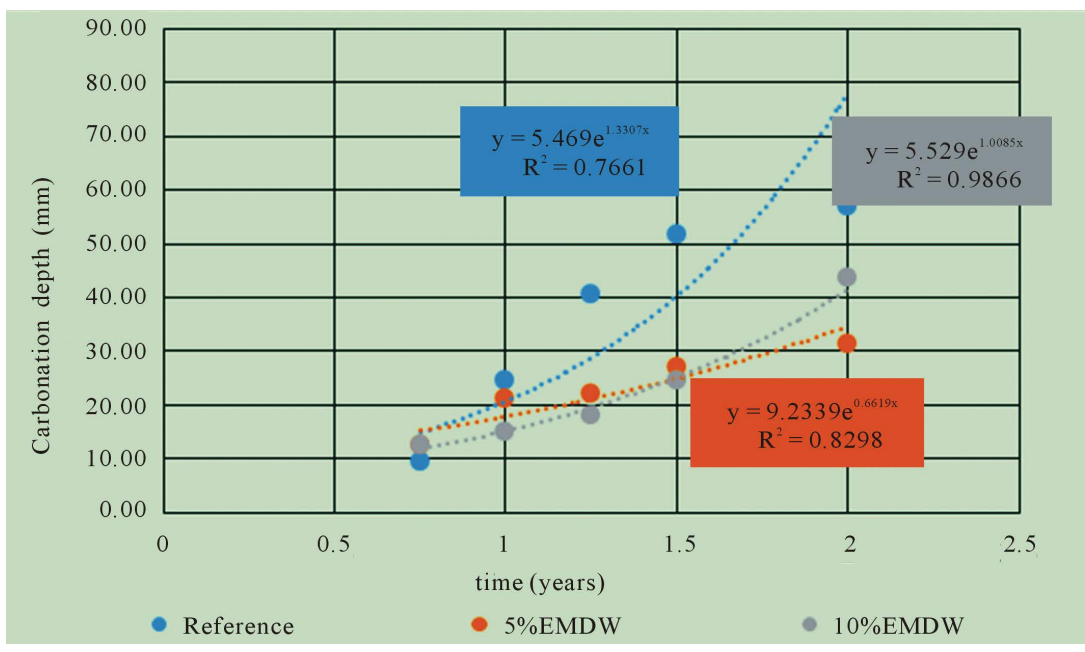

Figure 6. Carbonation depth (mm) of specimens exposed in atmosphere.

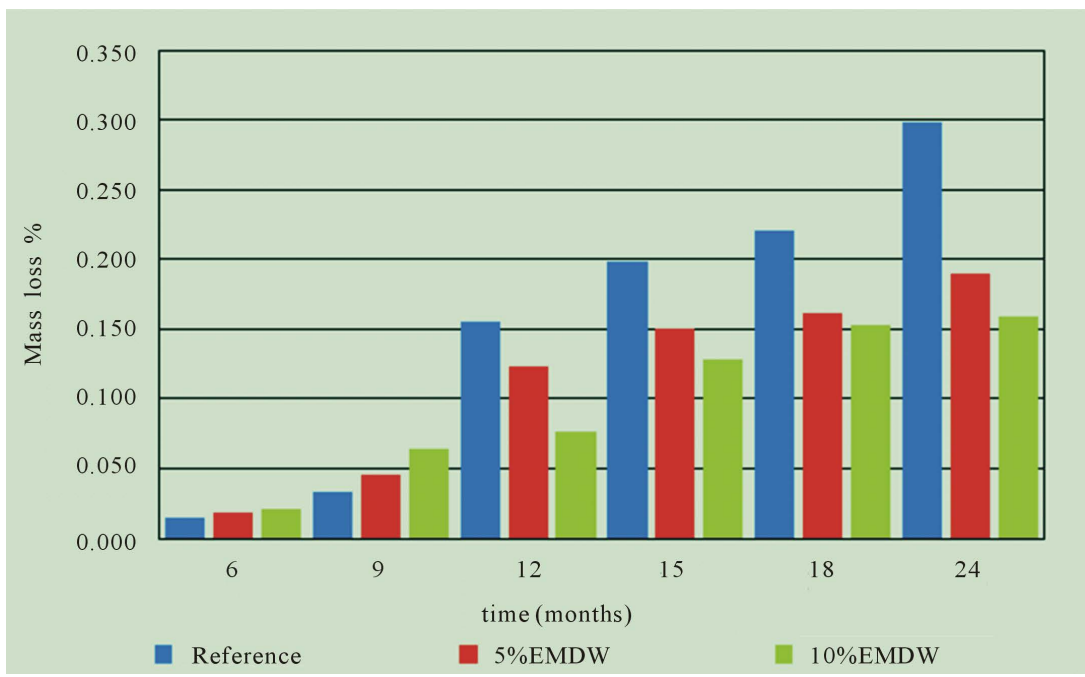

Figure 7. Mass loss (\%) of specimens exposed in atmosphere. 


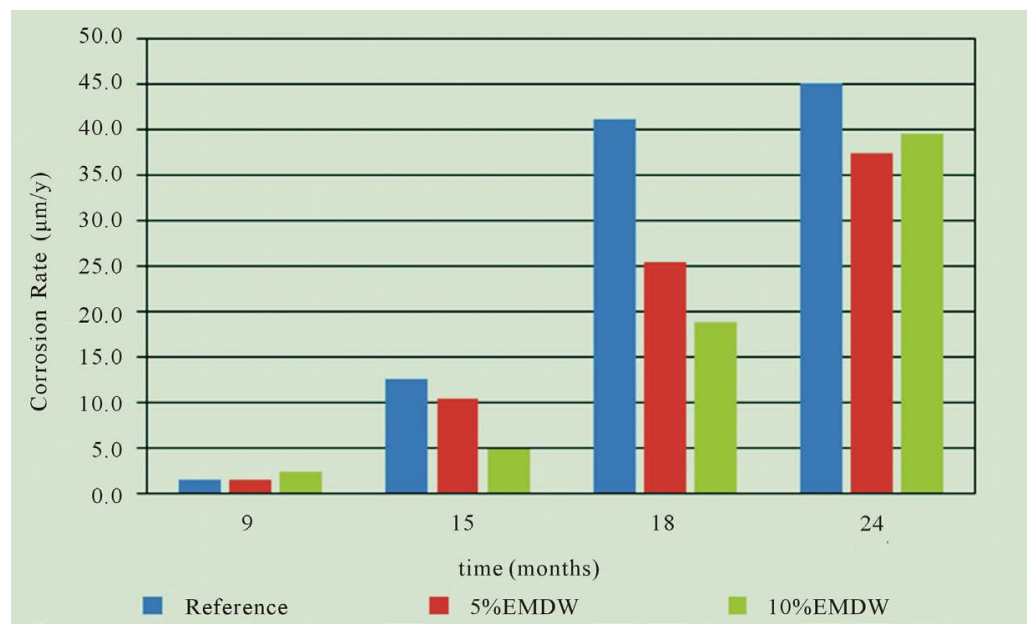

Figure 8. Corrosion rate $(\mu \mathrm{m} / \mathrm{y})$ of steel in $\mathrm{NaCl} 3.5 \%$ w.w solution.

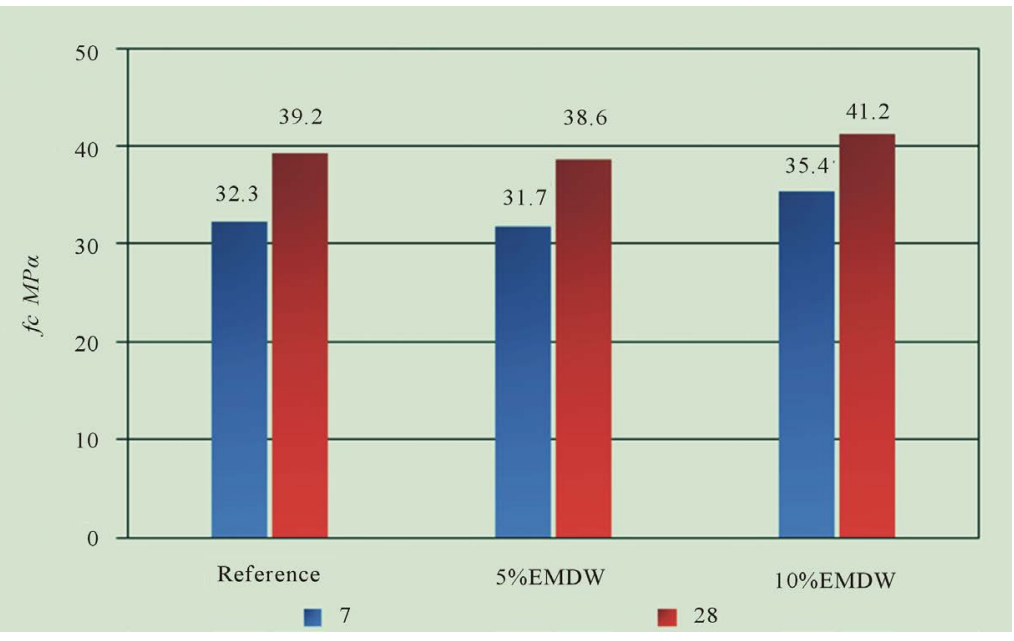

Figure 9. Compressive strength $(f c)$ of concrete (MPa).

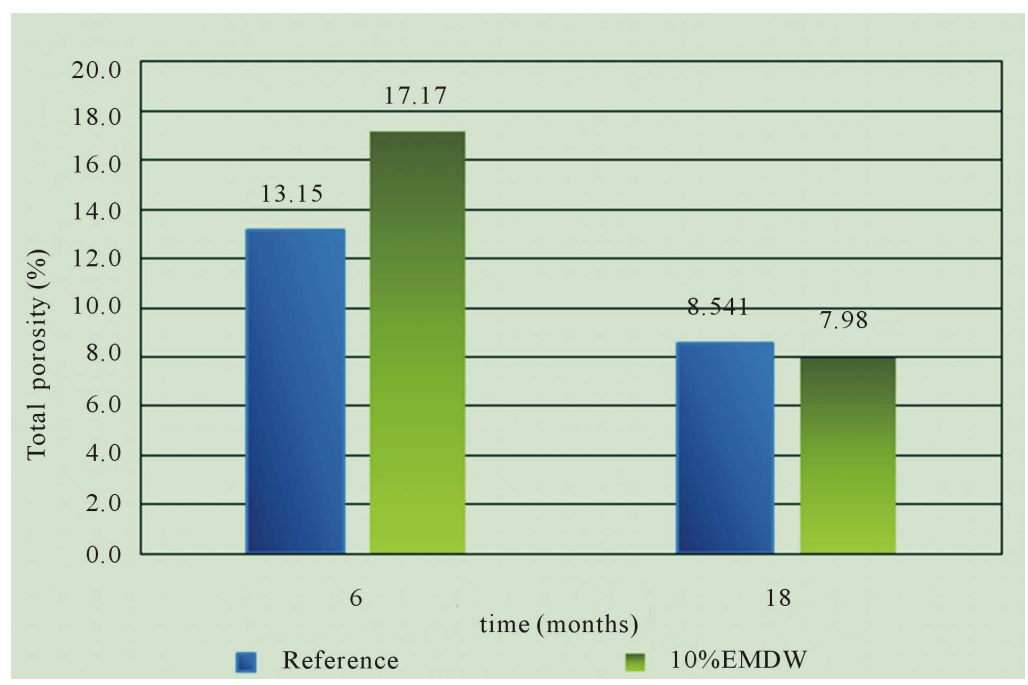

Figure 10. Total porosity (\%) of cement mortars exposed in atmosphere versus time by Mercury Intrusion Porosimetry method. 


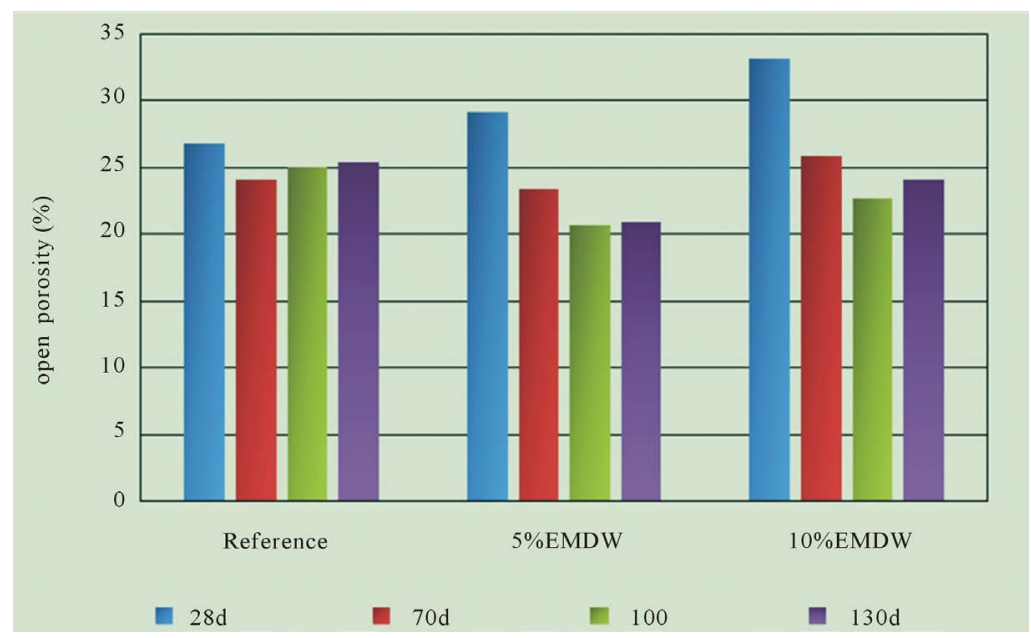

Figure 11. Open porosity (\%) of concrete specimens in $\mathrm{NaCl} 3.5 \%$ w. w solution by vacuum saturation method.

Table 8. Density measurements $\left(\mathrm{kg} / \mathrm{cm}^{3}\right)$ and slump $(\mathrm{mm})$.

\begin{tabular}{ccc} 
& Density $\left(\mathrm{kg} / \mathrm{m}^{3}\right)$ & \\
Reference & Period: 7 days & \\
2360 & $5 \%$ EMDW & $10 \%$ EMDW \\
- & 2358 & 2356 \\
& - & - \\
2349 & Period: 28 days & \\
& 2356 & 2351 \\
85 & Slump (mm) & 60 \\
\hline
\end{tabular}

In all cases the porosity decreased after 28 days of immersion in sodium Chloride solution. The additive containes Alunite and Jarosite and according to Katsioti et al. [35] the addition of jarosite-alunite up to $1 \%$ has no influence on the formation of the mineralogical phases but high content resulted in a higher ferrite proportion. Also, Chloride ions react with hydration products and generating Friedel's salt [36]. Based on the above, the high contents of calcite and iron of additive causes the reduction of porosity.

\section{Conclusions}

The following conclusions can be deduced from the present study:

- The replacement of cement by EMDW appears to significantly improve the durability of concrete against chloride ions;

- The addition of EMDW decreases the carbonation depth after 24 months of exposure in atmospheric conditions. High levels of Calcium and Iron increase the creation of C3S and C4AF which reduce the porosity and the diffusion of $\mathrm{CO}_{2}$;

- The compressive strength of specimens with $10 \%$ additive appears better than reference at early and late ages due to reduce permeability of concrete;

- The specimens with addition EMDW have lower values of gravimetric and theoretical mass loss than reference after partial immersion in $3.5 \% \mathrm{w}$. w $\mathrm{NaCl}$ solution;

- The total porosity of composite mortars exposed in atmosphere decreased more than specimens without EMDW addition;

- The use of additive reduced the open porosity more than reference from 70 days and then; 
- The addition of EMDW decreased the drying shrinkage. Between 7 and 28 days, the density of reference was reduced by $11 \mathrm{~kg} / \mathrm{m}^{3}$ and the specimens with $5 \%$ and 10\% EMDW, $2 \mathrm{~kg} / \mathrm{m}^{3}$ and $5 \mathrm{~kg} / \mathrm{m}^{3}$ respectively.

\section{References}

[1] Nawy, E.G. (2008) Concrete Construction Engineering Handbook. 2nd Edition, CRC Press, Boca Raton. http://dx.doi.org/10.1201/9781420007657

[2] Montemor, M.F., Simões, A.M.P. and Ferreira, M.G.S. (2003) Chloride-Induced Corrosion on Reinforcing Steel: From the Fundamentals to the Monitoring Techniques. Cement and Concrete Composites, 25, 491-502. http://dx.doi.org/10.1016/S0958-9465(02)00089-6

[3] Bastidas-Arteaga, E., Chateauneuf, A., Sánchez-Silva, M., Bressolette, Ph. and Schoefs, F. (2010) Influence of Weather and Global Warming in Chloride Ingress into Concrete: A Stochastic Approach. Structural Safety, 32, $238-249$. http://dx.doi.org/10.1016/j.strusafe.2010.03.002

[4] Kouloumbi, N. and Batis, G. (1992) Chloride Corrosion of Steel Rebars in Mortars with Fly Ash Admixtures. Cement and Concrete Composites, 14, 199-207. http://dx.doi.org/10.1016/0958-9465(92)90014-M

[5] Glass, G.K. and Buenfeld, N.R. (2000) The Influence of Chloride Binding on the Chloride Induced Corrosion Risk in Reinforced Concrete. Corrosion Science, 42, 329-344. http://dx.doi.org/10.1016/S0010-938X(99)00083-9

[6] Reddy, B., Glass, G.K., Lim, P.J. and Buenfeld, N.R. (2002) On the Corrosion Risk Presented by Chloride Bound in Concrete. Cement and Concrete Composites, 24, 1-5. http://dx.doi.org/10.1016/S0958-9465(01)00021-X

[7] Stewart, M.G., Wang, X.M. and Nguyen, M.N. (2012) Climate Change Adaptation for Corrosion Control of Concrete Infrastructure. Structural Safety, 35, 29-39. http://dx.doi.org/10.1016/j.strusafe.2011.10.002

[8] Ann, K.Y. and Song, H.-W. (2007) Chloride Threshold Level for Corrosion of Steel in Concrete. Corrosion Science, 49, 4113-4133. http://dx.doi.org/10.1016/j.corsci.2007.05.007

[9] Glass, G.K. and Buenfeld, N.R. (1997) The Presentation of the Chloride Threshold Level for Corrosion of Steel in Concrete. Corrosion Science, 39, 1001-1013. http://dx.doi.org/10.1016/S0010-938X(97)00009-7

[10] Bhargava, K., Ghosh, A.K., Mori, Y. and Ramanujam, S. (2005) Modeling of Time to Corrosion-Induced Cover Cracking in Reinforced Concrete Structures. Cement and Concrete Research, 35, 2203-2218. http://dx.doi.org/10.1016/j.cemconres.2005.06.007

[11] Broomfield, J.P., Langford, P.E. and Paull, R.J. (1987) Cathodic Protection for Reinforced Concrete: Application to Buildings and Marine Stuctures. Proceedings of the Fourth International Conference on Durability of Building Materials and Components, Singapore, 4-6 November 1987, 654-661. http://dx.doi.org/10.1016/B978-1-4832-8386-9.50090-5

[12] Broomfield, J.P. (2003) Corrosion of Steel in Concrete: Understanding, Investigation and Repair. 2nd Edition, E \& FN Spon, London.

[13] Rakanta, E., Zafeiropoulou, T. and Batis, G. (2013) Corrosion Protection of Steel with DMEA-Based Organic Inhibitor. Construction and Building Materials, 44, 507-513. http://dx.doi.org/10.1016/j.conbuildmat.2013.03.030

[14] Zafeiropoulou, T., Rakanta, E. and Batis, G. (2011) Performance Evaluation of Organic Coatings against Corrosion in Reinforced Cement Mortars. Progress in Organic Coatings, 72, 175-180. http://dx.doi.org/10.1016/j.porgcoat.2011.04.005

[15] Karoglou, M., Bakolas, A., Moropoulou, A. and Papapostolou, A. (2013) Effect of Coatings on Moisture and Salt Transfer Phenomena of Plasters. Construction and Building Materials, 48, 35-44. http://dx.doi.org/10.1016/j.conbuildmat.2013.06.050

[16] Batis, G., Pantazopoulou, P. and Routoulas, A. (2003) Corrosion Protection Investigation of Reinforcement by Inorganic Coating in the Presence of Alkanolamine-Based Inhibitor. Cement and Concrete Composites, 25, 371-377. http://dx.doi.org/10.1016/S0958-9465(02)00061-6

[17] Johnson, C.S. (2007) Development and Utility of Manganese Oxides as Cathodes in Lithium Batteries. Journal of Power Sources, 165, 559-565. http://dx.doi.org/10.1016/j.jpowsour.2006.10.040

[18] Panda, J.P., Sanjay, K., Ghosh, M.K. and Subbaiah, T. (2009) Electrolytic Manganese Dioxide (EMD) from Manganese Cake A Byproduct of Nodule Process. Proceedings of the 8th ISOPE Ocean Mining Symposium, Chennai, 20-24 September 2009.

[19] Brantley, F.E. and Rampacek, C. (1968) Process for Manganese Recovery from Leach Solutions. US 3397130 A.

[20] Zhang, W. and Cheng, C.Y. (2007) Manganese Metallurgy Review. Part I: Leaching of Ores/Secondary Materials and Recovery of Electrolytic/Chemical Manganese Dioxide. Hydrometallurgy, 89, 137-159.

http://dx.doi.org/10.1016/j.hydromet.2007.08.010 
[21] Hellenic Organization for Standardization ELOT 1421-3 (2005) Steel for the Reinforcement of Concrete-Weldable Reinforcing Steel—Part 3: Technical class B500C. Athens.

[22] ISO/DIS 8407.3 (1986) Procedures for Removal of Corrosion Products from Corrosion Test Specimen. Genève.

[23] American Society for Testing and Materials G59-97 (2003) Standard Test Method for Conducting Potentiodynamic Polarization Resistance Measurements. Vol. 3, No. 2.

[24] Stern, M. and Geary, A.L. (1957) Electrochemical Polarization. I. A Theoretical Analysis of the Shape of Polarization Curves. Journal of the Electrochemical Society, 104, 56-63. http://dx.doi.org/10.1149/1.2428496

[25] American Society for Testing and Materials C876-87 (1987) Standard Test Method for Half-Cell Potentials of Reinforcing Steel in Concrete. Vol. 3, No. 2.

[26] RILEM CPC-18 (1988) Measurement of Hardened Concrete Carbonation Depth.

[27] American Society for Testing and Materials C143/143M. Standard Test Method for Slump of Hydraulic-Cement Concrete. Vol. 4, No. 2.

[28] British Standard Institution BS EN 12390-3 (2009) Testing Hardened Concrete. Compressive Strength of Test Specimens. London.

[29] Washburn, E.W. (1921) The Dynamic of Capillary Flow. Physical Review, 17, 273. http://dx.doi.org/10.1103/PhysRev.17.273

[30] Kanellopoulos, A., Petrou, M.F. and Ioannou, I. (2012) Durability Performance of Self-Compacting Concrete. Construction and Building Materials, 37, 320-325. http://dx.doi.org/10.1016/j.conbuildmat.2012.07.049

[31] Theodoridou, M., Ioannou, I. and Philokyprou, M. (2013) New Evidence of Early Use of Artificial Pozzolanic Material in Mortars. Journal of Archaeological Science, 40, 3263-3269. http://dx.doi.org/10.1016/j.jas.2013.03.027

[32] Mansfeld, F. (1977) An Evaluation of Polarization Resistance Measurements. Materials and Corrosion, 28, 6-11. http://dx.doi.org/10.1002/maco.19770280103

[33] Angst, U., Elsener, B., Larsen, C.K. and Vennesland, Ø. (2009) Critical Chloride Content in Reinforced Concrete-A Review. Cement and Concrete Research, 39, 1122-1138. http://dx.doi.org/10.1016/j.cemconres.2009.08.006

[34] Neville, A.M. (1981) Properties of Concrete. Longman Scientific \& Technical, Pitman Publishing, London.

[35] Katsioti, M., Tsakiridis, P.E., Agatzini-Leonardou, S. and Oustadakis, P. (2005) Examination of the Jarosite-Alunite Precipitate Addition in the Raw Meal for the Production of Portland and Sulfoaluminate-Based Cement Clinkers. International Journal of Mineral Processing, 76, 217-224. http://dx.doi.org/10.1016/j.minpro.2005.01.007

[36] Suryavanshi, A.K., Scantlebury, J.D. and Lyon, S.B. (1996) Mechanism of Friedel’s Salt Formation in Cements Rich in Tri-Calcium Aluminate. Cement and Concrete Research, 26, 717-727. http://dx.doi.org/10.1016/S0008-8846(96)85009-5 